\title{
Recombinant human BMPs 2 and 4 expressed in mammalian cells aiming at bone tissue engineering and stem cell proliferation and differentiation
}

\author{
Ana Claudia O Carreira ${ }^{1 *}$, Erik Halcsik¹, Paula Mota de Sá', Felipe Zattar ${ }^{1}$, José Mauro Granjeiro², \\ Mari Cleide Sogayar'
}

From 5th Congress of the Brazilian Biotechnology Society (SBBIOTEC)

Florianópolis, Brazil. 10-14 November 2013

\section{Background}

Bone Morphogenetic Proteins (BMPs) are multifunctional, secreted cytokines belonging to the TGF- $\beta$ superfamily. These proteins act as a disulfide-linked homodimer, being potent regulators of bone and cartilage formation and repair, cell proliferation in embryonic development and adult bone homeostasis. BMPs are promising molecules in periodontal regeneration to treat physiopathological bone loss and non-union fractures and in oral surgery, and to accelerate and increase osseointegration. BMPs are dimeric molecules displaying sites for $\mathrm{N}$ - and $\mathrm{O}$-glycosylation, which increases the stability and half-life of the protein in the body, in addition to determining the specificity of receptor coupling. BMP-2 induces cartilage and bone formation. BMP4 has also been shown to play a role in triggering osteoblastic differentiation of mesenchymal stem cells, through activation of osteoblastic related genes. In order to ensure proper glycosylation and conformational folding and to prevent immunogenicity, we elected a mammalian cell expression system to produce these BMPs aiming at bone regeneration, stem cell proliferation and differentiation and their application in human and veterinary cell therapy.

\section{Methods}

BMPs 2 and 4 cDNAs were amplified from an in-house constructed cDNA Bank and cloned into the $\mathrm{pGEM}^{\mathbb{B}}-\mathrm{T}$ Easy vector. E. coli transformants were screened by

\footnotetext{
${ }^{1}$ Chemistry Institute, Biochemistry Department; and Cell and Molecular Therapy Center NUCEL-NETCEM, School of Medicine; University of São Paulo, São Paulo, SP; Brazil

Full list of author information is available at the end of the article
}

colony PCR. Upon DNA sequencing, the BMP 2 and 4 inserts were transferred to a lentiviral expression vector. HEK293 cells were co-transfected with a lentiviral plasmid containing both BMP 2 or 4 and eGFP cDNAs, by co-transfection, at a 40:1 ratio, with a Hygro ${ }^{\mathrm{r}}$ vector for clone selection. Cell clones were selected using $100 \mathrm{ug} /$ $\mathrm{mL}$ hygromicin. Several cell clones were characterized and highest overproducing ones were selected for each protein. BMPs expression was analyzed by qRT-PCR, Western blotting, and in vitro biological activity by alkaline phosphatase activity in $\mathrm{C} 2 \mathrm{C} 12$ cells during 7 days. Recombinant proteins were purified using heparin affinity chromatography.

\section{Results and conclusions}

Upon cell cloning, most of the cells present in the selected clones were positive for GFP, indicating that a high transfection efficiency was achieved. BMPs 2 and 4 were continuously secreted to the medium even after $120 \mathrm{~h}$ of serum starvation. Purification of rhBMP2 and 4 from the conditioned medium resulted in more than $90 \%$ purity. The rhBMPs 2 and 4 bound to the resin were eluted in $450 \mathrm{mM} \mathrm{NaCl}$ buffer, with a single dimeric 30-37 kDa band being observed in the eluates. In vitro assays showed that the purified rhBMPs 2 and 4 displayed high osteogenic activity. The in vivo osteogenic bioactivity analysis of the purified proteins by ectopic bone formation using Rowett rats is underway. Glycosylation analysis using exoglicosidase digestion and structural analysis of the purified proteins is underway. The use of these biopharmaceuticals in bone Tissue 
Engineering is likely to allow accelerated recovery to both human patients and animals.

\section{Acknowledgements}

BNDES, CAPES, CNPq, FAPESP, FAPERJ, FINEP, MCTI and MS-DECIT.

\section{Authors' details}

${ }^{1}$ Chemistry Institute, Biochemistry Department; and Cell and Molecular Therapy Center NUCEL-NETCEM, School of Medicine; University of São Paulo, São Paulo, SP; Brazil. 'Bioengineering Division, National Institute of Metrology, Quality, and Technology, Duque de Caxias, RJ, Brazil; and Department of Dental Materials, Dental School, Fluminense Federal University, Niteroi, RJ, Brazil.

Published: 1 October 2014

\section{References}

1. Granjeiro JM, Oliveira RC, Bustos-Valenzuela JC, Sogayar MC, Taga R: Bone morphogenetic proteins: from structure to clinical use. Braz Med Biol Res 2005, 38(10):1463-1473.

2. Bustos-Valenzuela JC, Halcsik E, Bassi EJ, Demasi MA, Granjeiro JM, Sogayar MC: Expression, purification, bioactivity, and partial characterization of a recombinant human bone morphogenetic protein7 produced in human 293T cells. Mol Biotechnol 2010, 46(2):118-26, doi: 10.1007/s12033-010-9287-0.

3. Urist MR, Nogami $H$, Mikulski A: A bone morphogenetic polypeptide. Calcified Tissue Research Calcif Tissue Res 1976, 21(Suppl):81-7.

doi:10.1186/1753-6561-8-S4-P84

Cite this article as: $O$ Carreira et al:: Recombinant human BMPs 2 and 4 expressed in mammalian cells aiming at bone tissue engineering and stem cell proliferation and differentiation. BMC Proceedings 2014

8(Suppl 4):P84.

\section{Submit your next manuscript to BioMed Central} and take full advantage of:

- Convenient online submission

- Thorough peer review

- No space constraints or color figure charges

- Immediate publication on acceptance

- Inclusion in PubMed, CAS, Scopus and Google Scholar

- Research which is freely available for redistribution 